\title{
Protecting and preserving South African aeolianite surfaces from graffiti
}

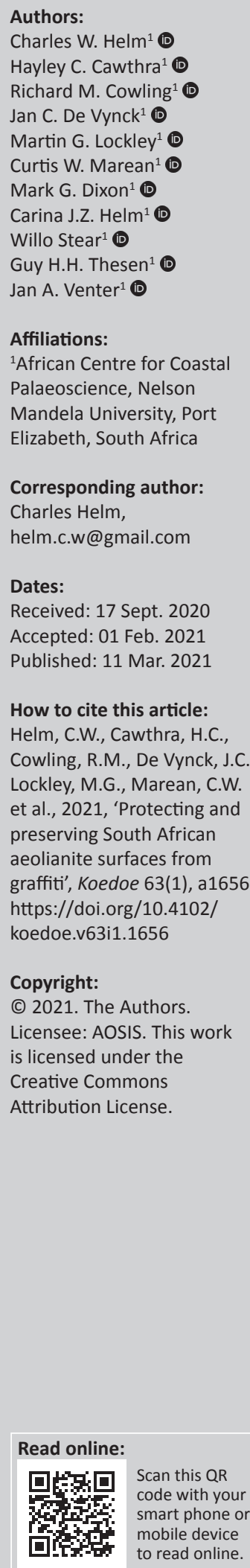

Pleistocene aeolianite surfaces on the South African coastline, which occur in national parks, other protected areas, as well as unprotected areas, are of profound scientific, cultural, palaeoenvironmental and heritage importance. A threat is posed to these surfaces by the increasing presence of graffiti, which may deface or destroy fossil tracksites and other evidence of events that transpired on these surfaces when they were composed of unconsolidated sand tens of thousands of years ago. Increased awareness of the importance of this heritage resource is desirable, along with the development of strategies to prevent further damage.

Keywords: protected areas; management; Pleistocene; conservation; graffiti.

Aeolianite surfaces on the South African coastline are of profound scientific, cultural, palaeoenvironmental and heritage importance, and a threat is posed to these surfaces by graffiti artists. The South African aeolianites are not only an outstanding, global example of this rock type, but are also sensitive palaeoenvironmental indicators. They happen to occur in an area of critical importance for palaeoanthropology and, hence, in the study of human origins.

Research on the Cape south coast, for example, has documented the oldest known working of ochre and adornment through its use (Marean et al. 2007:905-908); ornamentation in the form of perforated Nassarius krausssianus shells (D'Errico et al. 2005:3-24); bone awl and bone tool manufacturing (Henshilwood et al. 2001:632-678); development of microlithic technology (Brown et al. 2012:590-593); heat treatment of stone tools (Brown et al. 2009:859-862); early art, or the use of abstract symbols, as engravings in ochre (e.g. Henshilwood et al. 2002:1278-80), a drawing on a silcrete flake (Henshilwood et al. 2018:115-118), and engravings on ostrich eggshells (Henshilwood et al. 2014:284-303); the first use of marine or intertidal resources by humans, and the first systematic exploitation of these resources (Marean et al. 2007:905-908; Marean 2010:425-443). In combination, these innovations strongly indicate the emergence of cognitive complexity in our species (Wadley 2015:155-226).

The coastal aeolianites are cemented Pleistocene dune surfaces, and the cemented foreshore deposits represent Pleistocene beach surfaces. They crop out intermittently along the South African coast, and occur in, for example, West Coast National Park, Garden Route National Park, Addo Elephant National Park, adjacent protected areas such as Goukamma Nature Reserve, and within numerous unprotected areas. Whilst the majority have been dated to 90 000-130 000 years (e.g. Bateman et al. 2011:63-81; Cawthra et al. 2018:156-172; Roberts et al. 2008:261-279), the age of these rocks extends from $\sim 35000$ years at Robberg (Carr et al. 2019:1-15) to 400000 years at Dana Bay (Roberts et al. 2012:226-237), and as much as 720000 years in a cave at Pinnacle Point (Pickering et al. 2013:39-52).

Since 2007, we have, through the Cape south coast ichnology project, documented more than 250 fossil vertebrate tracksites in these rock surfaces (Helm et al. 2020a:1-15). Thus, we know that they have the capacity to faithfully record, sometimes in exquisite detail, the events that transpired on them when they were composed of unconsolidated sand tens of thousands of years ago. Some tracks represent the traces of extinct members of the Pleistocene megafauna (e.g., the long-horned buffalo, giant Cape zebra and Cape subspecies of the African lion). Others provide evidence, which is not available through the traditional body fossil record, of the presence of creatures that no longer inhabit the region, such as hatchling sea turtles (Lockley et al. 2019:626-640), crocodiles, giraffe and large avian forms, with resulting palaeoenvironmental inferences (Helm et al. 2020a:1-15). These tracksites would have been situated at the margin of the vast, now-submerged, Palaeo-Agulhas Plain, harbouring an extinct ecosystem that was of pivotal significance for early modern human beings (Marean, Cowling \& Franklin 2020:1-17). 
In addition, these exceptional rocks provide evidence of the activity of our ancestors: To date, six hominin tracksites have been identified (Helm et al. 2018a:1-13, 2020b:1-13; Roberts 2008:190-207), providing the oldest known ichnological evidence of Homo sapiens, thereby complementing the documented Middle Stone Age archaeological record from the Cape coast. Sometimes, erosive forces acting on tracksites lead to the development of remarkably beautiful sculpted forms. Aeolianite surfaces on the southern African coastline, therefore, are of profound scientific, cultural, palaeoenvironmental, heritage and aesthetic importance.

Unfortunately, their relatively soft, friable nature makes them suitable canvases for graffiti artists. A hammer and chisel can easily deface or completely destroy these surfaces, and their scientific, heritage and aesthetic attributes. Repeat visits indicate that this is an active problem, and that the prevalence of graffiti is increasing. Possibly, the presence of graffiti acts as an incitement to other potential graffiti artists. A notable example is from Kraalbaai in West Coast National Park, where Roberts (2008:190-207) identified hominin tracks now famously known as 'Eve's Footprints', dated to 117 000 years. This surface was found in an area with multiple examples of graffiti (Figure 1a). A graffiti artist had reached the surface containing the hominin tracks first; through good fortune, the graffiti narrowly missed defacing the tracks. Nonetheless, a decision was taken that airlifting the trackbearing aeolianite slab to the Iziko Museum in Cape Town constituted the most secure means of preservation.

The outcome was less fortunate at Brenton-on-Sea, an area that now also boasts at least one hominin tracksite (Helm et al. 2018b:1-13). In a small cave, the sloping floor is adorned with multiple examples of graffiti, as a result of which the underlying trackways are deformed beyond recognition and interpretation. Tragically, there were indications, noted by our research team, that these may also have been hominin tracks (Figure 1b).

At another site, in Goukamma Nature Reserve (Helm et al. 2020b:1-13), graffiti (Figure 1c) has been observed within a few metres of a hominin tracksite. Graffiti in the shape of letters and hearts may be readily identifiable as such, but abstract or older examples have the potential to create identification challenges in the interpretation of such sites, which we regard as an unwelcome intrusion.

We have observed that tracksites seem to encourage the creative urge in the graffiti artist, as such sites appear to harbour a disproportionate amount of recent etchings, either in direct association with the tracks or on adjacent surfaces. A surface at Brenton-on Sea that contains well-preserved Late Pleistocene invertebrate burrow traces also contains deeply etched graffiti (Figure 1d). Furthermore, a surface on a fallen slab in Garden Route National Park is unusual, in that it not only contains etched graffiti, but also the resulting grooves have been daubed with an erosion-resistant black substance, making the graffiti visible from a considerable distance (Figure 1e). Unfortunately, the graffiti transects the only example we have observed thus far of a Late Pleistocene lagomorph (hare) trackway. Another area that we have examined in the Goukamma Nature Reserve (Helm et al. 2018b:89-101), which comprises a dense concentration of fossil tracksites, including the longest long-horned buffalo trackway thus far identified, also contains its share of graffiti.

Areas with a high public recreational presence not surprisingly also exhibit a larger amount of graffiti. However, an example from the rocks near the mouth of the Great Brak River illustrates a rare positive effect of graffiti: a large fallen block, from a layer dated to 121 000 years (Cawthra et al. 2018:156-172), contained a substantial flat surface, which attracted graffiti artists, and this came to be known as 'Graffiti Rock'. Then around 2010, the surface layer failed and much of it broke off, probably as a result of the pounding by hammers and chisels. This 4-cm-thick layer tumbled into the river, leaving just a small corner of graffiti as a reminder, and exposing a number of bovid trackways on the underlying surface, which were identified by our team (Figure 1f). These trackways provided the first unequivocal evidence of Pleistocene vertebrates leaving their tracks on beaches in southern Africa (Helm et al. 2021:59-74). However, this result is an exception to a trend of increasing destruction and vandalism.

There are sites in the Western Cape, such as the Heerenlogement (near Graafwater: https:/ / sahris.sahra.org. $\mathrm{za} /$ node/15040) and the Herrieklip (in Meiringspoort: https:/ /sahris.sahra.org.za/sites/920680010), where examples of lettering that was carved into rock surfaces, as much as three centuries ago, have been declared provincial historic sites. While such sites may be of historical importance, we are not aware of such significance for any of the graffiti found on aeolianite surfaces. It appears that the erodible nature of these surfaces prevents graffiti (and tracksites) from enduring for more than a few generations. We also noted that while some forms of graffiti can be erased (e.g., paint on walls in public spaces), defacement of aeolianite surfaces is essentially irreversible.

We noted a regrettable irony with regard to the hominin tracksites. The surfaces that recorded the footprints and activities of our own species became buried and, over time, became cemented, and then became re-exposed through forces of erosion. It is incredibly fortuitous that such reexposed surfaces occur in southern Africa, where our distant ancestors 'found their feet', and that they are available to us for interpretation. Yet, some modern-day descendants of those ancestral pioneers carve new forms into those surfaces, sometimes before any scientific appraisal can occur.

What can be performed to stop this phenomenon? While regulations and punitive fines may have their place, prevention through education and awareness may be more suitable. Examples of graffiti on trees and in association with rock art can be used to inform such discussion. For example, in cases involving etching into ancient trees, signage can alert 

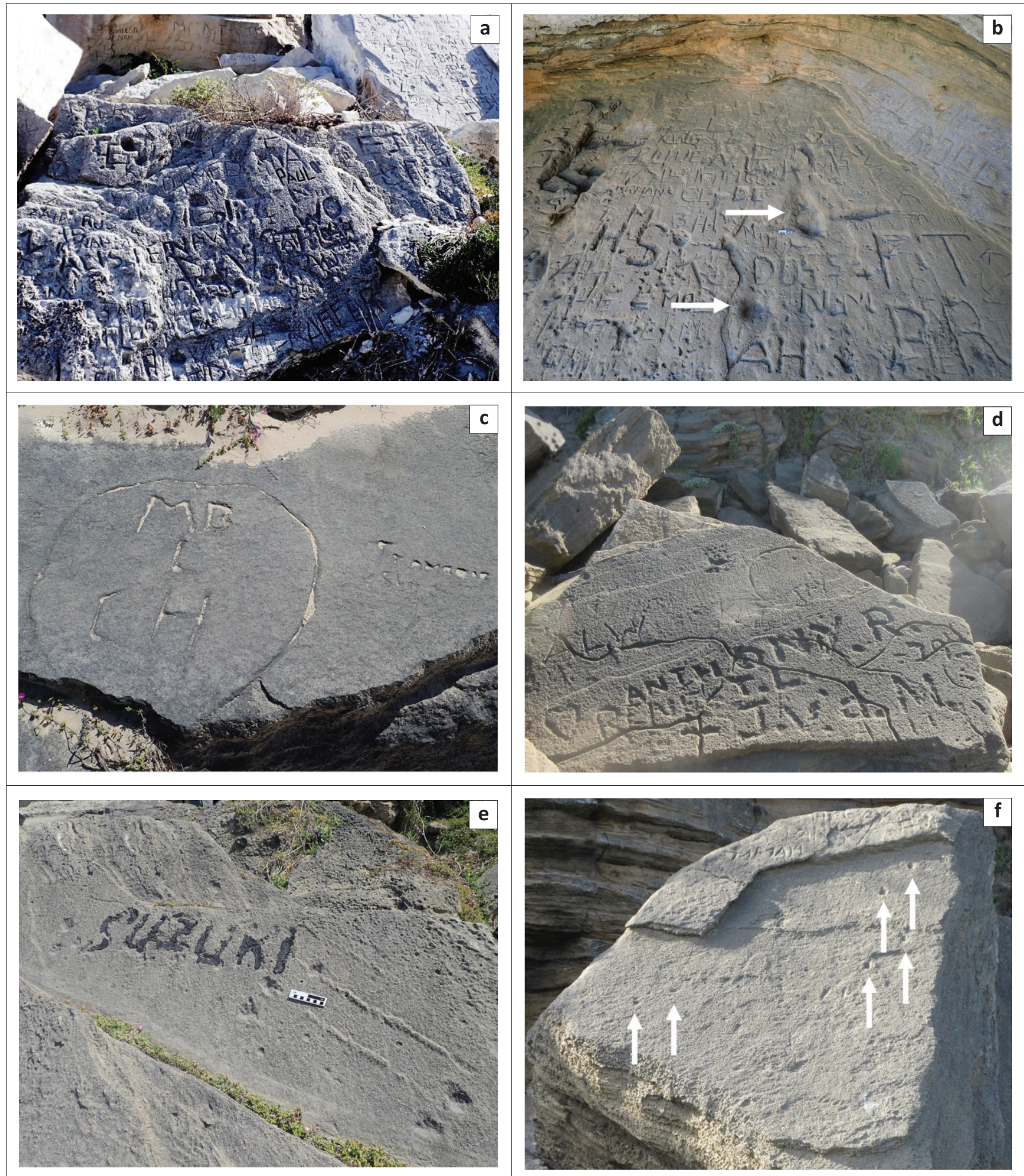

Source: Photographs by Charles Helm

FIGURE 1: (a) Dense concentrations of graffiti on aeolianites at Kraalbaai, West Coast National Park; (b) graffiti on a cave floor surface at Brenton-on-Sea, rendering what may have been hominin tracks (two of which are indicated with arrows) undecipherable; (c) graffiti on an aeolianite surface in Goukamma Nature Reserve, metres from an important hominin tracksite; (d) graffiti on a loose aeolianite slab exhibiting well-preserved invertebrate burrow traces; (e) graffiti crossing a lagomorph trackway in Garden Route National Park; (f) bovid tracks (indicated by white arrows) exposed on a cemented foreshore deposit surface at Great Brak River following the failure of a superficial graffiti layer - vestigial areas of graffiti are evident on the overlying layer.

visitors to the dangers of such behaviour, and can direct would-be graffiti artists to nearby alternative stumps on which they can ply their craft. Over time, the importance of not defacing rock art sites has been appreciated, although the only certain means of protection in some cases has been to construct physical barriers and gates, despite the associated 
aesthetic drawbacks, for example, at Schaapplaats in Free State province (Ouzman 2000:8-10).

Unfortunately, access to areas of the aeolianite-containing coastline is harder to prevent. Signage at access points to areas of coastline could include catch phrases such as 'Please don't destroy in five minutes what took 120000 years to form'. While we are uncertain as to their potential effectiveness, display boards explaining what aeolianites are and emphasising their geological and ichnological importance could be erected at such access points - much like signs that provide information on archaeological sites and coastal fauna and flora. Because many aeolianites occur in South Africa's national parks and other protected areas, we suggest that authorities such as SANParks and CapeNature are well placed to lead such initiatives, ideally in collaboration with municipalities that have jurisdiction over unprotected areas.

Regardless of how this issue is eventually approached, we believe that the initial step consists simply of promoting an awareness of the importance of protecting aeolianites amongst preservation-minded people. Aeolianites are remarkable rock types, and their surfaces may be worthy of protection in their own right. However, we make the case that their heritage and scientific value strengthen the argument for their protection. It is our view that this value is often underappreciated, and the scientific importance of an aeolianite surface may not readily be apparent to a nonichnologist. Furthermore, whilst aeolianites worldwide are worthy of protection, the information that can be gleaned from them regarding hominin origins places the South African examples in a unique context and makes them of critical international importance.

\section{Acknowledgements}

The support of SANParks and Cape Nature in providing permission for the authors to study Pleistocene palaeosurfaces in national parks and nature reserves is appreciated. The authors wish to acknowledge the two anonymous peer reviewers who provided insightful contributions, and the input of the editor.

\section{Competing interests}

The authors declare that they have no financial or personal relationships that may have inappropriately influenced them in writing this letter.

\section{Authors' contributions}

C.W.H., H.C.C., R.M.C., J.C.D.V., M.G.L., C.W.M., M.G.D., C.T.Z.H., W.S., G.H.H.Y. and J.A.V contributed to and agreed upon the contents of the scientific letter.

\section{Ethical consideration}

This article followed all ethical standards for a research without direct contact with human or animal subjects.

\section{Funding information}

The authors received no financial support for the research, authorship and/or publication of this letter.

\section{Data availability}

The authors confirm that the data supporting the findings of this study are available within the letter.

\section{Disclaimer}

The views expressed in the submitted letter are those of the authors and do not necessarily reflect the official policy or position of any affiliated agency of the author.

\section{References}

Bateman, M.D., Carr, A.S., Dunajko, A.C., Holmes, P.J., Roberts, D.L., McLaren, S.J. et al., 2011, 'The evolution of coastal barrier systems: A case study of the MiddleLate Pleistocene Wilderness barriers, South Africa', Quaternary Science Reviews 30(1-2), 63-81. https://doi.org/10.1016/j.quascirev.2010.10.003

Brown, K.S., Marean, C.W., Herries, A.I.R., Jacobs, Z., Tribolo, C., Braun, D. et al., 2009 'Fire as an engineering tool of early modern humans', Science 325(5982), 859-862. https://doi.org/10.1126/science.1175028

Brown, K.S., Marean, C.W., Jacobs, Z., Schoville, B.J., Oestmo, S., Fisher, E.C. et al., 2012, 'An early and enduring advanced technology originating 71000 years ago in South Africa', Nature 491(1), 590-593. https://doi.org/10.1038/nature11660

Carr, A.S., Bateman, M.D., Cawthra, H.C. \& Sealy, J., 2019, 'First evidence for on-shore Marine Isotope Stage 3 aeolianite formation on the southern Cape coastline of South Africa', Marine Geology 407(1), 1-15. https://doi.org/10.1016/j. margeo.2018.10.003

Cawthra, H.C., Jacobs, Z Compton, J.S, Fisher, E.C. Karkanas, P. \& Marean, C.W 2018, 'Depositional and sea-level history from MIS 6 (Termination II) to MIS 3 on the southern continental shelf of South Africa', Quaternary Science Reviews 181(1), 156-172. https://doi.org/10.1016/j.quascirev.2017.12.002

D’Errico, F., Henshilwood, C., Vanhaeren, M. \& Van Niekerk, K., 2005, ‘Nassarius kraussianus shell beads from Blombos Cave: Evidence for symbolic behaviour in the Middle Stone Age', Journal of Human Evolution 48(1), 3-24. https://doi. org/10.1016/j.jhevol.2004.09.002

Helm, C.W., Cawthra, H.C., Cowling, R.M., De Vynck, J.C., Lockley, M.G., Marean, C.W. et al., 2020a, 'Pleistocene vertebrate tracksites on the Cape south coast of South Africa and their potential palaeoecological implications', Quaternary Science Reviews 235(1), Article ID 105857. https://doi.org/10.1016/j.quascirev.2019. 07.039

Helm, C.W., Cawthra, H.C., De Vynck, J.C., Dixon, M. \& Stear, W., 2021, 'Elephant tracks - A biogenic cause of potholes in Pleistocene South African coastal rocks', Journal of Coastal Research 37(1), 59-74. https://doi.org/10.2112/JCOASTRESD-20-00064.1

Helm, C.W., Lockley, M.G., Cawthra, H.C., De Vynck, J.C., Dixon, M.G., Helm, C.J.Z. et al., 2020b, 'Newly identified hominin trackways from the Cape south coast of South Africa', South African Journal of Science 116(9/10), Art. \#8156, 13 pages. https://doi.org/10.17159/sajs.2020/8156

Helm, C.W., McCrea, R.T., Cawthra, H.C., Cowling, R.M., Lockley, M.G., Marean, C.W. et al., 2018a, 'A new Pleistocene hominin tracksite from the Cape south coast, South Africa', Scientific Reports 8(1), 3772. https://doi.org/10.1038/s41598018-22059-5

Helm, C.W., McCrea, R.T., Cawthra, H.C., Thesen, G.H.H. \& Mwankunda, J.M., 2018b, 'Late Pleistocene trace fossils in the Goukamma Nature Reserve, Cape south coast, South Africa', Palaeontologia Africana 52(1), 89-101.

Henshilwood, C., D’Errico, F., Marean, C., Milo, R. \& Yates, R., 2001, 'An early bone tool industry from the Middle Stone Age at Blombos Cave, South Africa: Implications for the origins of modern human behaviour, symbolism and language', Journal of Human Evolution 41(6), 632-678. https://doi.org/10.1006/ jhev.2001.0515

Henshilwood, C.S., D'Errico, F., Van Niekerk, K.L., Dayet, L., Queffelec, A. \& Pollarolo, L., 2018, 'An abstract drawing from the 73,000-year-old levels at Blombos Cave, South Africa', Nature 562(1), 115-118. https://doi.org/10.1038/s41586-0180514-3

Henshilwood, C.S., D’errico, F., Yates, R., Jacobs, Z., Tribolo, C., Duller, G.A.T. et al., 2002, 'Emergence of modern human behavior: Middle Stone Age engravings from South Africa', Science 295(5588), 1278-1280. https://doi.org/10.1126/science. 1067575

Henshilwood, C.S., Van Niekerk, K.L., Wurz, S., Delagnes, A., Armitage, S.J., Rifkin, R.F. et al., 2014, 'Klipdrift Shelter, southern Cape, South Africa: Preliminary report on the Howiesons Poort layers', Journal of Archaeological Science 45(1), 284-303. https://doi.org/10.1016/j.jas.2014.01.033 
Lockley, M.G., Cawthra, H.C., De Vynck, J.C., Helm, C.W., McCrea, R.T. \& Nel, R., 2019 'New fossil sea turtle trackway morphotypes from the Pleistocene of South Africa highlight role of ichnology in turtle palaeobiology', Quaternary Research 92(3), 626-640. https://doi.org/10.1017/qua.2019.40

Marean, C.W., 2010, 'Pinnacle Point Cave 13B (Western Cape Province, South Africa) in context: The Cape Floral kingdom, shellfish, and modern human origins', Journal of Human Evolution 59(3-4), 425-443. https://doi.org/10.1016/j.jhevol. 2010.07.011

Marean, C.W., Bar-Matthews, M., Bernatchez, J., Fisher, E., Goldberg, P., Herries, A.I.R. et al., 2007, 'Early human use of marine resources and pigment in South Africa during the Middle Pleistocene', Nature 449(7164), 905-908. https://doi.org/ 10.1038/nature06204

Marean, C.W., Cowling, R.C. \& Franklin, J., 2020, 'The Palaeo-Agulhas Plain: Temporal and spatial variation in an extraordinary extinct ecosystem of the Pleistocene of the Cape Floristic Region', Quaternary Science Reviews 235(1), Article ID 106161. https://doi.org/10.1016/j.quascirev.2019.106161 Ouzman, S., 2000, 'Public rock art sites of the Free State: Schaapplaats', Culna 55(1),
Pickering, R., Jacobs, Z., Herries, A.I.R., Karkanas, P., Bar-Matthews, M., Woodhead, J.D. et al., 2013, 'Paleoanthropologically significant South African sea caves dated to $1.1-1.0$ million years using a combination of U-Pb, TT-OSL and palaeomagnetism', Quaternary Science Reviews 6(1), 39-52. https://doi. palaeomagnetism', Quaternary Scienc
org/10.1016/j.quascirev.2012.12.016

Roberts, D.L., 2008, 'Last Interglacial hominid and associated vertebrate fossi trackways in coastal eolianites, South Africa', Ichnos 15(3), 190-207. https://doi. trackways in coastal eolianites, Sou
org/10.1080/10420940802470482

Roberts, D.L., Bateman, M.D., Murray-Wallace, C.V., Carr, A.S. \& Holmes, P.J., 2008 'Last interglacial fossil elephant trackways dated by OSL/AAR in coastal aeolianites, Still Bay, South Africa', Palaeogeography, Palaeoclimatology, Palaeoecology 257(3), 261-279. https://doi.org/10.1016/j.palaeo.2007.08.005

Roberts, D.L., Karkanas, P., Jacobs, Z., Marean, C.W. \& Roberts, R.G., 2012, 'Melting ice sheets $400,000 \mathrm{yr}$ ago raised sea level by $13 \mathrm{~m}$ : Past analogue for future trends', Earth and Planetary Science Letters 357-358(1), 226-237. https://doi. org/10.1016/j.epsl.2012.09.006

Wadley, L., 2015, 'Those marvellous millennia: The Middle Stone Age of southernmost Africa', Azania 50(2), 155-226. https://doi.org/10.1080/0067270X.2015.1039236 